\title{
Subjective Well-Being analysis of Minang adolescents based on parents' socio-economic status and gender
}

\section{Indah Rizki Ramadani ${ }^{1}$, Herman Nirwana ${ }^{1}$}

${ }^{1}$ Universitas Negeri Padang

${ }^{*}$ Corresponding author, e-mail: herman.talawi@gmail.com

\begin{abstract}
One of the factors that influence subjective well-being (SWB) is socioeconomic status and gender. This study aims to analyze the differences in SWB of Minang adolescents based on socioeconomic status and gender. The research method used quantitative descriptive comparative with a sample of 182 Minang teenagers (9 people with high socioeconomic status, 76 moderate, and 97 people with low socioeconomic status, or 48 men and 134 women). The instruments used are the Socio-Economic Status List and the SWB Filling List. The data were analyzed using the Kolmogorov Smirnov test and the $\mathrm{T}$ test. The results showed that there was no difference in the SWB of Minang adolescents based on the socioeconomic status of their parents and by gender.
\end{abstract}

Keywords: Subjective Well-Being, Parents' Socio-Economic Status, and Gender

How to Cite: Ramadani, I.R., Nirwana, H. (2021). Subjective Well-Being analysis of Minang adolescents based on parents' socio-economic status and gender. International Journal of Applied Counseling and Social Sciences, 2 (2): pp. 154-160, DOI: https://doi.org/10.24036/005436ijaccs

This is an open access article distributed under the Creative Commons 4.0 Attribution License, which permits unrestricted use, distribution, and reproduction in any medium, provided the original work is properly cited. @2021 by Author

\section{Introduction}

Every individual (including teenagers) wants a happy, healthy, and prosperous life. Not a few teenagers who want to be born in perfect physical condition and come from a family with a higher socio-economic status so that they can feel well in life (Ramdhani, Wimbarti, \& Susetyo, 2018). Family is an internal factor that plays a very important role in supporting the improvement of adolescent welfare, the higher the role of the family, the higher the subjective well-being of the teenager (Prabowo, 2016; Nayana, 2013).

Welfare in life can be divided into two, namely; (1) subjective well-being, and (2) objective well-being (Milligan \& Fabian, 2006). Subjective welfare is seen as the ability of adolescents to fulfill their life needs, as if welfare in life is only for someone who is said to be economically capable. (Astuti, 2017). While objective welfare is based on assumptions about the basic needs of human life and their rights in life (Mulyadi, 2018). 
The subjective well-being of adolescents is influenced by many factors, one of which is socio-economic status (Gloria, 2015), so that the higher the socio-economic level of the individual, the higher the SWB tends to be. In adolescents, subjective well-being is one indicator of quality of life that can reduce the presence of mental stress so that adolescents are required to suppress negative emotions as factors that can hinder well-being, so that adolescents can increase high creativity, it can be realized from the diligent, persistent, and optimistic in living life (Diener, Oishi, \& Lucas, 2003). In other words, adolescents with high SWB tend to have positive impacts on their lives, such as good physical health, higher life expectancy, being comfortable with themselves, having a better social life, being more altruistic, more conflict resolution, and tending to be successful in their life many areas of life.

Economic conditions often make individuals independent in learning because they are accustomed to without parental assistance or awareness of economic conditions that make them able to be independent and motivated in learning so that their subjective well-being increases. This is proven by using an open ended questionnaire on poor families in improving the subjective welfare of children in the city of Padang (Mudjiran, Niken, \& Rinaldi, 2017).

Subjective well-being in adolescents is influenced by many factors, namely the level of happiness of adolescents with harmonious family conditions, attention from parents, friends or a warm environment, adequate learning facilities and socioeconomic status. But in reality not all happiness can be realized because of differences in socioeconomic status. According to Abdulsyani (2012) socio-economic status is the position or position of a person determined by education, income and type of work. A number of studies show that the economic level of the family is also one of the factors that determine family harmony. Jorgensen found in his research that the higher the economic resources of the family, the higher the stability and happiness of the family (Jorgensen, 2007). Research conducted by Gloria et al, shows that the relationship between happiness and socioeconomic status is very small (Wenas \& Opod, 2015).

Socio-economic status in society is divided into three levels, namely upper class, middle class, and lower class. (Sunarto, 2004). Based on the degree of dependence on the standard of living society dimension, the level of community welfare can be divided into well-being subsystems, namely; (1) social subsystem and (2) economic subsystem, covering human welfare, social welfare, consumption, poverty level, and economic and other activities (World Bank Institute, 2004).

Financial problems tend to interfere with the smooth education of teenagers. Many youths are forced to drop out of school due to financial problems, and have to find work to help their parents make ends meet. Hamalik (2002) said that differences in parental education level, economic level, family attitude towards social problems, economic understanding, language vocabulary, ability to communicate with others, thinking motivation, speaking habits and ways of working together with others will greatly affect behavior and actions in teaching and learning activities at school.

Low economic conditions will cause; (1) lack of learning tools, (2) lack of fees that have been prepared by parents, and (3) lack of good learning facilities (Ahmadi \& Widodo, 2004). In families with low economic conditions, it can also be the cause of malnutrition in adolescents so that their growth and development will be disrupted and other needs cannot be met. Lack of economy also causes the atmosphere at home to be gloomy so that teenagers lose their enthusiasm for learning (Sobur, 2011). 
Culture greatly affects subjective well-being (Diener, 2020). Relations welfare of society, culture with subjective well-being can be explained by the perception of society in each country about the importance of the concept of happiness (Diener, Suh, Lucas, \& Smith, 1999). Differences in cultural norms can also affect positive affect and negative affect, positive affect is more influenced by cultural norms than negative affect. A culture that assumes that expressing positive affect is not good, adolescents will show less positive affect.

Unlike other cultures in Indonesia, Minangkabau is a culture that is the only matriarchal culture, where the lineage is taken from the mother's side. Thus, women have a special position in the social system, so that women are nicknamed with "bundo kanduang" or limpapeh rumah nan gadang. Term bundo kanduang This means that women have an important role in prioritizing policies, considerations, and harmony in society. That role lies in the hands of women (mothers) who are wise. Term limpapeh rumah nan gadang, which is a place where all members of the rumah gadang hold deliberation. Besides that, limpapeh rumah nan gadang has the meaning of the hope of all family members or residents rumah gadang. In short, the welfare and harmony of all family members depends on the wisdom of women as women bundo kanduang and limpapeh rumah gadang (Nirwana, 2003). Therefore, the inheritance system and family regulation on the female side is more important than the male side (Amir, 2011).

Minangkabau identical by the teachings of Islam, attitudes and norms in everyday life Minangkabau society must be based on religion and customs (Imelda, 2017). Deviations between Minangkabau customs and Islam bring their own consequences, both from customary and religious regulations that cannot be ignored in regulating the life and lives of the Minang people. The backgrounds of the two families may be very different, both from origin, language, living habits, education, level of social status, manners, and so on. (Amir, 2011).

In this study, Minangkabau culture will be the focus of culture which will be studied extensively and in depth so that it can be seen the extent to which cultural linkages affect adolescent subjective well-being. Differences in the level of parental socioeconomic status can encourage adolescents to have different subjective well-being assessments. This study aims to analyze the subjective well-being of Minang adolescents based on the socioeconomic status of their parents (high, medium, low) and the subjective well-being of Minang adolescents (male and female).

\section{Method}

The method used in this study is a quantitative method with a descriptive type of comparison. Descriptive type is used to describe SWB based on socioeconomic status and gender; while the type of comparison is used to compare the SWB of Minang adolescents based on socioeconomic status and gender.

The study population was all students of SMA Negeri 1 Batipuh in Tanah Datar Regency with a Minangkabau cultural background, who were enrolled in the January-June 2021 semester, with a sample of 182 Minang teenagers (9 people with high socioeconomic status, 76 moderate, and 97 people with low socioeconomic status). low socioeconomic status, or 48 men and 134 women) selected by stratified random sampling technique. 
The research instrument used is the Subjective Well-Being List, the Parents' Socio-Economic Status List, and the Gender List. The analytical technique used to describe the SWB is descriptive statistics, and for the analysis of the SWB difference test based on socioeconomic status is the Kolmogorov Smirnov test and the T test, and for the analysis of the SWB difference test based on gender is the $\mathrm{T}$ test analysis technique. All of these analyzes use computer services, namely the SPSS version 20.00 program.

\section{Results and Discussion}

\section{Minang Adolescent SWB Analysis based on Socio-Economic Status}

Table 1 on the next page shows that the average (mean) SWB score of Minang adolescents from moderate socioeconomic status is higher than the average (mean) SWB score of Minang adolescents from low socio-economic status. Where the average score (mean) of Minang teenagers from low socio-economic status is 196,0412 with an SD of 20,72082, while the average score of Minang teenagers from moderate socioeconomic status is 193,1316, with an SD of 21,18134. Although the average SWB score of Minang adolescents of moderate socioeconomic status is higher than the average SWB score of Minang adolescents of low socio-economic status, there is no statistically significant difference with a $\mathrm{T}$ value of 0.908 and a significance of 0.365. Likewise, when compared to the SWB of Minang adolescents between moderate socioeconomic status and high socioeconomic status, there is also no significant difference. In short, there is no difference in the SWB of Minang adolescents based on socio-economic status. In other words, socioeconomic status has nothing to do with SWB. High SWB exists in adolescents from low, medium, and middle socio-economic status.

The findings of this study are in agreement with the two previous studies. For example research Wahyuni (2018), where the level of SWB for early childhood is high even though they come from families with low socioeconomic status; Aryogi (2016), where there is no relationship between income and adult SWB levels. In other words, an increase in income is not always followed by an increase in SWB. Based on the findings of the research above and previous studies, it can be concluded that socioeconomic status has no contribution to individual SWB, including Minang adolescents.

Tabel 1. Subjective Well-Being Difference Test for Minang Teenagers

Between Low-Medium Socio-Economic

\begin{tabular}{|lc|c|c|c|c|}
\hline & Sosial Ekonomi & N & Mean & Std. Deviation & Std. Error Mean \\
\hline \multirow{2}{*}{ Subjective Well-Being } & 1.00 (low) & 97 & 196.0412 & 20.72082 & 2.10388 \\
& 2.00 (medium) & 76 & 193.1316 & 21.18134 & 2.42967 \\
\hline
\end{tabular}

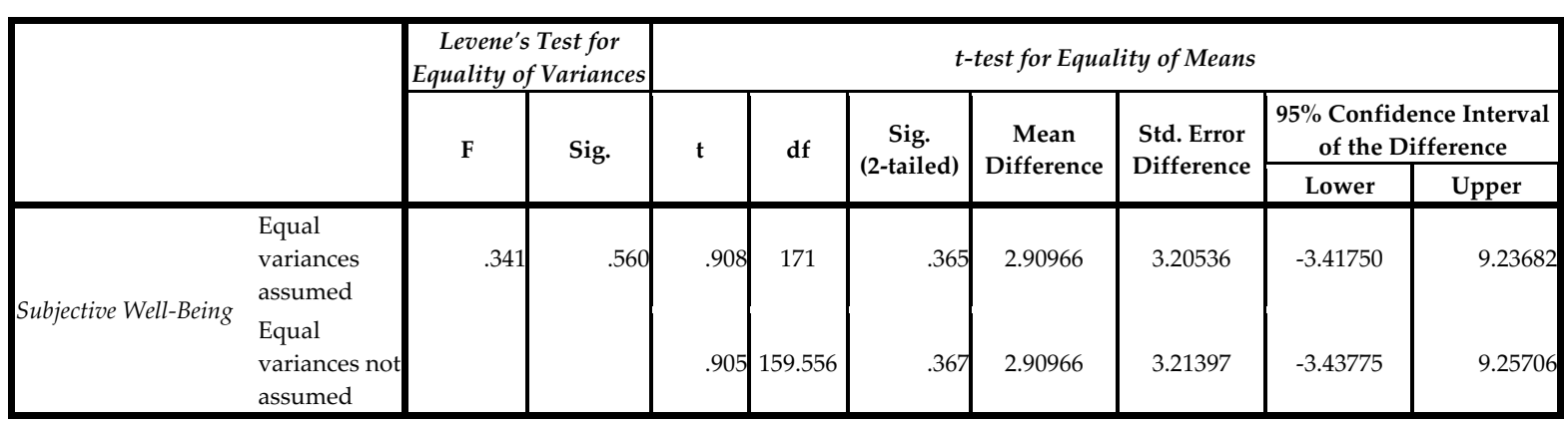




\section{Tabel 2. Subjective Well-Being Difference Test for Minang Teenagers Between male and Female students}

\begin{tabular}{|l|l|c|c|c|c|}
\hline & Jenis Kelamin & $\mathrm{N}$ & Mean & Std. Deviation & Std. Error Mean \\
\hline \multirow{2}{*}{ Subjective Well-Being } & 1.00 (pria) & 48 & 193.8750 & 19.88544 & 2.87022 \\
& 2.00 (wanita) & 134 & 194.3881 & 22.04333 & 1.90425 \\
\hline
\end{tabular}

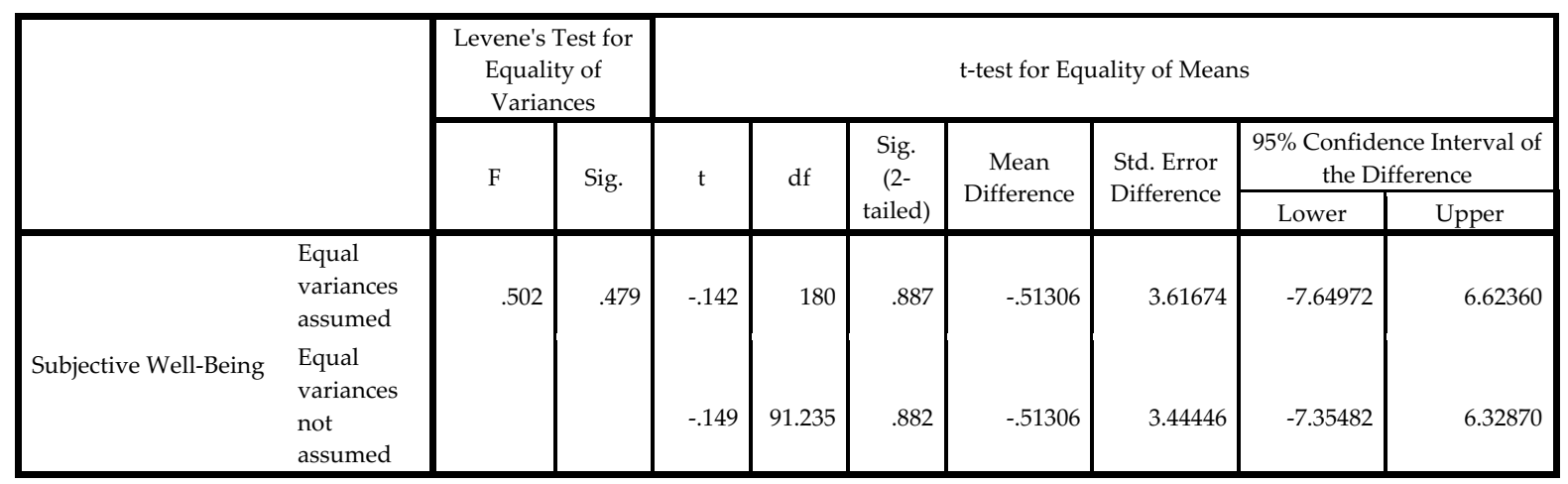

\section{SWB Analysis of Minang Adolescents by Gender}

The differences in SWB of Minang adolescents by gender (male and female) are summarized in Table 2. In Table 2 shows the average SWB score of Minang adolescents for male is 1693.87 with Sd 19.88; while the average SWB score for female Minang teenagers is 194.38 with an Sd of 22.04. Although the mean (mean) SWB of male Minang adolescents is higher than the mean (mean) of female SWB scores, there is no statistically significant difference, where Tcount is 0.142 with a significance of 0.887 . In other words, there is no relationship between gender and SWB for Minang teenagers.

When compared with previous studies, the results of this study are in agreement. For example research Triyana (2018), which shows that there is no difference in student SWB by gender. So is research Utami (2009), which shows there is no difference in student SWB between male and female students. Thus, this study strengthens the results of previous studies that there is no link between the sex of an individual and his SWB. In other words, SWB can be enjoyed by both male and female individuals.

\section{Conclusion}

Based on the results of the research and discussion above, it can be concluded that there is no difference in the SWB of Minang adolescents based on their parents' socio-economic status, although the average SWB score of adolescents from a medium socio-economic status background is higher than the average SWB score of those with low socio-economic status. Likewise with the SWB analysis by gender, there was no difference in the SWB of Minang adolescents between male and female adolescents. In short, there is no relationship between socio-economic status and gender with SWB. SWB can be enjoyed by individuals from low, medium, and high socioeconomic status; or by young men and women. Considering that there is no relationship between socio-economic status and gender with SWB, further research needs to be done to examine other variables that are related or contribute to SWB for Minang adolescents, for example the variables of gratitude, self-esteem, meaning of life, and social support from peers. 


\section{References}

Abdulsyani. (2012). Sosiologi Skematika, teori dan Terapan. Jakarta: Bumi Aksara.

Ahmadi, A \& Widodo, S. (2004). Psikologi Belajar. Jakarta: Rineka Cipta.

Aryogi, I \& Wulansari D. (2016). Subjective Well-being Individu dalam Rumah Tangga di Indonesia. Jurnal Ilmu Ekonomi Terapan. 01 (1):1-12.

Astuti. (2017). Pemetaan Tingkat Kesejahteraan Keluarga di Kecamatan Banjarmasin Selatan. JPG (Jurnal Pendidikan Geografi).

Diener, Ed, Oishi, S., \& Lucas, R. E. (2003). Personality, culture, and subjective well-being: Emotional and cognitive Evaluations of Life. Annual Review of Psychology, 54(1), 403-425. https://doi.org/https://doi.org/10.1146/annurev.psych.54.101601.145056

Diener, Ed, Suh, E. M., Lucas, R. E., \& Smith, H. L. (1999). Subjective Well-Being: Three Decades of Progress. Psychological Bulletin, 125(2), 276.

Ed. Diener. (2020). Ilmu Kesejahteraan Seri Penelitian Indikator Sosial. New York: Springer Dordrecht Heidelberg London.

Gloria, W, Henry O. (2015). Hubungan Kebahagiaan dan Status Sosial Ekonomi. Jurnal eBiomedik, 3(1), 532-538.

Imelda, A. (2017). Implementasi Pendidikan Nilai Dalam Pendidikan Agama Islam. AlTadzkiyyah: Jurnal Pendidikan Islam, 8(2), 227-247.

Jorgensen, B. . (2007). Financial Literacy of College Student: Parental and Peer Influences. Virginia.

Sunarto, K. (2004). Pengantar Sosiologi (3 ed.). Lembaga Penerbit Fakultas Ekonomi, Universitas Indonesia.

Milligan, S., Fabian, A., \& Coope, P. C. (2006). Family well-being indicators from the 1981-2001. New Zealand Censuses

Mudjiran, N. H. dan, \& Rinaldi. (2017). Optimalisasi Pengasuhan pada Keluarga Miskin dalam Rangka Meningkatkan Kesejahteraan Subjektif Anak di Kota Padang. Jurnal RAP (Riset Aktual Psikologi Universitas Negeri Padang), 8(1), 158-169. http://ejournal.unp.ac.id/index.php/psikologi/article/view/7955

Mulyadi, M. (2018). Kesejahteraan, Kualitas Hidup dan Kaitannya dengan Lingkungan Hidup. Padang: Universitas Negeri Padang.

Nayana, F. N. (2013). Kefungsian Keluarga dan Subjective Well-Being Pada Remaja. Jurnal Ilmiah Psikologi Terapan (JIPT), 01(02), 230-244.

Nirwana, H. (2003). Hubungan Tingkat Aspirasi dan Persepsi Tentang Belajar dengan Hasil Belajar Matematika Siswa Sekolah Menengah Umum yang Berlatar Belakang Budaya Minangkabau dan Batak. Disertasi. Psikoklogi Pendidikan, Pascasarjana Universitas Negeri Malang.

Hamalik, O. (2002). Psikologi Belajar Mengajar. Bandung: Sinar Baru Grasindo.

Prabowo, A. (2016). Kesejahteraan Psikologis Remaja di Sekolah. Jurnal Ilmiah Psikologi Terapan (JIPT), 4(2), 246-260. 
Putri, R.D. (2015). Peran Dukungan Sosial dan Kecerdasan Emosi Terhadap Kesejahteraan Subjektif Pada Remaja Awal. Yogyakarta: Universitas Gadjah Mada:

Ramdhani, N., Wimbarti, S., \& Susetyo, Y. F. (2018). Psikologi untuk Indonesia Tangguh dan Bahagia. Yogyakarta: UGM Press.

Saifullah, dkk. (2017). Pertautan Budaya Sejarah Minangkabau dan Negeri Sembilan. Sumatera Barat: Institut Seni Indonesia (ISI) Padang Panjang.

Sobur, A. (2011). Psikologi Umum. Bandung: Pustaka Setia.

Sunarto,K. (2004). Pengantar Sosiologi (3 ed). Jakarta: Lembaga Penerbit Fakultas Ekonomi, Universitas Indonesia.

Triyana Pz \& Soeharto. (2018). Subjective Well-Being Pada Mahasiswa Ditinjau dari Dukungan Sosial Teman Sebaya dan Jenis Kelamin. Prosiding Seminar Nasional 2018 Fakultas Psikologi Universitas Diponegoro.153-160.

Utami, S. M. (2009). Keterlibatan dalam Kegiatan dan Kesejahteraan Subjektif Mahasiswa. $36(2)$.

Wahyuni, S., Reswita, \& R. (2018). Subjective Well-Being Anak yang Berasal dari Keluarga Berstatus Sosial Ekonomi Rendah. Pendidikan. 9(2):149-160.

World Bank Institute. (2004). Dasar-Dasar Analisis Kemiskinan (Edisi Terj). Semarang. 